\title{
Non-linear study of base shear and moment of composite columns in MRFs
}

\author{
Amir Parviz Khosravi Amiri \\ Lecturer and Postgraduate of Structural Engineering, Department of Civil Engineering, Young Researchers \\ and Elite Club, Roudehen Branch, Islamic Azad university, Roudehen, Iran \\ E-mail: acamir.slap@yahoo.com
}

Copyright () 2015 Amir Parviz Khosravi Amiri. This is an open access article distributed under the Creative Commons Attribution License, which permits unrestricted use, distribution, and reproduction in any medium, provided the original work is properly cited.

\begin{abstract}
The main objective of this study is evaluating the seismic behavior of composite columns in MRFs subject to dynamic loads.

The design Codes of composite structures contain different views in some cases and therefore conservative provisions, because of lack of enough information about the behavior of these structures. The base shear and moment of structures in non-linear state can be considered as criteria for the potential of a lateral-force-resisting system to dissipate the seismic energy.

Lower values of non-linear seismic base reactions indicate better efficacy of the system. In this study the performance of the MRFs with composite columns has been evaluated using 8-story structural models, considering the base reactions obtained from the non-linear analysis. Analytical modeling has been performed based on the AISC Code. The results show good performance of composite sections under the seismic loads. Also, a comparison between two types of composite sections, the full and half-embedded steel sections in concrete, has been made.
\end{abstract}

Keywords: Base Moment , Base Shear, Composite Columns, Non-Linear Study.

\section{Introduction}

Structures with large values of seismic base shear and moment have more stiffness and less ductility compared with structures that have lower values of base reactions in the same conditions. Such structures cannot dissipate the seismic energy effectively because of lack of enough ductility and plastic deformations. According to Begum et al. one of the challenges for structural designers is to prevent the local buckling of steel columns while having economic design of structural members [1]. This problem has been solved by using composite structures, a combination of steel and concrete materials. The benefits of these structural systems relative to more common systems include their performance characteristics when subjected to service or ultimate loads, and their economy with respect both to material and construction (hajjar) [2]. Ellobody et al. presents a nonlinear 3-D finite element model for eccentrically loaded concrete encased steel composite columns. The columns were pin-ended subjected to an eccentric load acting along the major axis. Generally, it is shown that the effect on the composite column strength owing to the increase in structural steel yield stress is significant for eccentrically loaded columns with small eccentricity of 0.125D [3]. Saw and Liew presents the design assessment of encased I-sections and concrete filled composite columns based on the approaches given in Eurocode 4: Part 1.1, BS 5400: Part 5 and AISC LRFD [4]. Estekanchi presents application of the ET method (is a time-history based dynamic pushover procedure for seismic analysis and design of structures) in linear seismic analysis of structures has been investigated [5]. Gramblicka presents some results of the analysis of the effects of the second order theory for the theoretical analysis of composite steel concrete columns was made a computational program [6]. The design Codes of composite structures contain conservative provisions in some cases because of lack of enough experimental information in this area. It justifies further researches on actual behavior of composite structures because 
of its high importance. In this study the performances of different types of composite sections have been evaluated and compared with steel sections. The benefits of using composite sections have also been shown.

\section{Purpose and methodology}

The main objective of this study is evaluating and comparison between different types of composite columns, subjected to seismic loading, considering nonlinear behavior. In this regard, the seismic behavior of 8-stories Moment Resisting Frames with different composite sections of columns, i.e. Type 1; embedded IPB sections in concrete, Type 2; thinwalled steel sections filled with concrete, and Type 3; half-embedded IPB sections in concrete, has been studied. Structural analyses have been performed based on the Iranian Code of Practice for Seismic Resistant Design of Buildings (Standard No. 2800). Four plastic-designed structural models have been considered. These models are 8stories moment resisting frames, including Model 8-1 (with steel columns of IPB section), Model 8-2 (with composite columns of section Type 1), Model 8-3 (with composite columns of section Type 2) and Model 8-4 (with composite columns of section type 3). For non-linear analysis, software which is capable to model the geometry of composite sections as well as the structural non-linear behavior is needed. In this study the software Seismostruct (Version 5.2.1) has been used. Also, three accelerogams, i.e. Tabas, Northridge and ChiChi records have been used for the time history analyses. The specifications of these accelerograms are shown in Table 1.

Table 1: Accelerogram Specifications

\begin{tabular}{lllll}
\hline Record & PGA $(\mathrm{g})$ & PGV $(\mathrm{cm} / \mathrm{s})$ & Name & Dimension $[\mathrm{mm}]$ \\
\hline Tabas & 0.406 & 26.5 & 0.02 & 25 \\
Northridge & 0.358 & 27.5 & 0.02 & 40 \\
ChiChi & 0.364 & 55.4 & 0.004 & 150 \\
\hline
\end{tabular}

\section{Analytical modeling}

The plastic moment of composite column sections are calculated using the following formulas:

$$
\begin{aligned}
& N_{P}=\alpha_{b} \sigma_{b r} F_{b}+\sum \alpha_{a} \sigma_{F} F_{a} \\
& y=\frac{\alpha_{a} \sigma_{F}\left(F_{a}+2 b_{a} c\right)}{\alpha_{b} \sigma_{b r} b+2 \alpha_{a} \sigma_{F} b_{a}} \\
& M_{P}=\alpha_{a} \sigma_{F}\left[F_{a} \frac{d-y}{2}-b_{a} c(y-c)\right]+\alpha_{a}^{\prime} \sigma_{F}^{\prime} F_{a}^{\prime} \frac{d^{\prime}}{2}
\end{aligned}
$$

Where;

$\alpha_{b}$ is reduction factor for concrete, $F_{a}$ is section area of steel, $\alpha_{a}$ is reduction factor of steel, $\sigma_{b r}$ is compressive strength of concrete, $\mathrm{F}_{\mathrm{b}}$ is section area of concrete, and $\sigma_{\mathrm{F}}$ is yield strength of steel.

Table 3: Values of $\mathrm{Nu}$ and $\mathrm{Mu}$ in Composite Columns of Type I

\begin{tabular}{lllll}
\multicolumn{5}{c}{ Table 3: Values of Nu and Mu in Composite Columns of Type I } \\
\hline Section & Dimension $(\mathrm{cm})$ & Profile & Mp (t.m) & Np (t) \\
\hline CC1-IPB12 & $22 * 22$ & IPB12 & 5.31 & 190 \\
CC1-IPB14 & $24 * 24$ & IPB14 & 8.5 & 230 \\
CC1-IPB16 & $26 * 26$ & IPB16 & 12 & 275 \\
CC1-IPB18 & $28 * 28$ & IPB18 & 15.5 & 320 \\
CC1-IPB20 & $30 * 30$ & IPB20 & 20 & 375 \\
CC1-IPB22 & $32 * 32$ & IPB22 & 25 & 430 \\
CC1-IPB24 & $34 * 34$ & IPB24 & 31.5 & 490 \\
CC1-IPB26 & $36 * 36$ & IPB26 & 37.5 & 545 \\
CC1-IPB28 & $38 * 38$ & IPB28 & 44.7 & 600 \\
CC1-IPB30 & $40 * 40$ & IPB30 & 51.8 & 656 \\
CC1-IPB12 & $22 * 22$ & IPB12 & 5.31 & 190 \\
\hline
\end{tabular}

\section{Simulation characteristics}

The occupancy of structures is considered as residential with the importance factor of 1.0 .The lateral force resisting system is the Intermediate Moment Resisting Frame (according to Table 6 of Standard No. 2800). Gravitational loads are considered based on volume 6 of the Iranian National Building Codes, means the dead load of $600 \mathrm{~kg} / \mathrm{m} 2$, the live load of $200 \mathrm{~kg} / \mathrm{m} 2$ and the roof live load of $150 \mathrm{~kg} / \mathrm{m} 2$ have been taken into account. 
Table 2: Assumptions of Design

\begin{tabular}{ll}
\hline characteristic & value \\
\hline Design-basis acceleration & $\mathrm{A}=0.35$ \\
Soil type 2 & $\mathrm{Ts}=0.5, \mathrm{~T} 0=0.1$ \\
Importance factor & $\mathrm{I}=1$ \\
Response reduction factor & $\mathrm{R}=7$ \\
\hline
\end{tabular}

\section{Results and discussion}

Considering that the designed frames are symmetric in geometry and loading, and considering this symmetry is also applicable to the obtained seismic base reactions, only four corner columns in the plan have been evaluated for comparison of the results (Fig. 1). Fig. 2 which is obtained based on the analytical results shows that the maximum base shear and moment in models are resulted from the Chichi earthquake and the minimum base reactions are resulted from the Tabas earthquake.

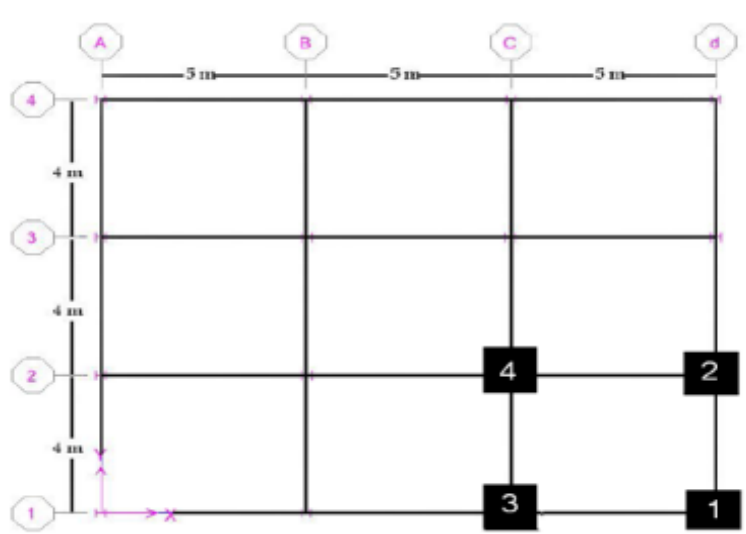

Fig. 1: Considered Support Joints In the Plan for Comparing the Results

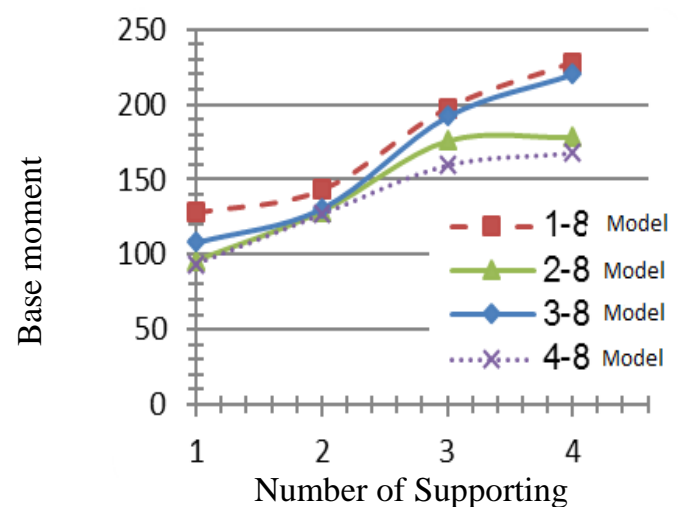

Fig. 2: Base Moments at Supporting Joints, Chichi Excitation

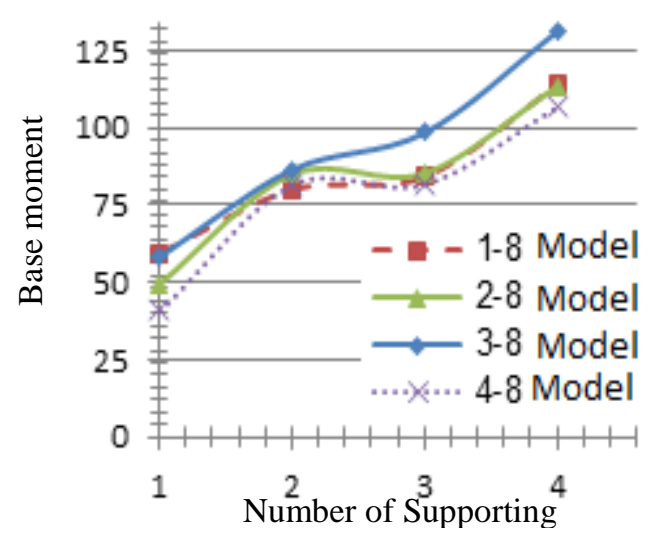

Fig. 3: Base Moments at Supporting Joints, Northridge Excitation 


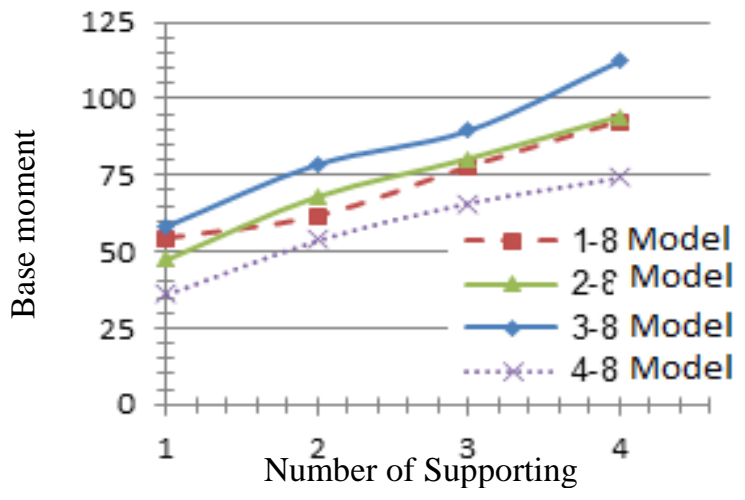

Fig. 4: Base Moments at Supporting Joints, Tabas Excitation

Based on the recommendation of Iranian Seismic Code, the accelerogram which results in the maximum responses of structure should be considered for the design purposes among the other accelerograms which have been used for the analysis of the structure. Therefore, the ChiChi earthquake has been selected for further study and analysis of the models. The obtained results from analysis of 8-stories models show that Model 8-1 has the maximum seismic base moments in all considered supports. This is due to the relative stiffness of the structure. Among the different composite models, the Model 8-4 has the least values of base moment at supporting joints. Models 8-4 and 8-2 have almost the same base moments at the supporting joints No. 1, 2 and 4. Model 8-2 has greater base moments at the supporting joint No. 3. It shows that the designed structures using composite sections Type 1 and Type 3 have similar non-linear behaviors. They have good performances in dissipating the input energy, especially in high rise buildings. However, in the Model 8-3, greater base moments have been resulted at support joints No. 1 to 4, because of large column sections, and therefore heavy weight of the structure, so, increasing the stiffness and decreasing the ductility of the structure. Comparison of the obtained seismic base shears in 8-stories MRFs, show almost similar results.

\section{Conclusion}

Based on the non-linear analysis of different composite columns in 8-stories MRFs which have been performed under dynamic loading, it is concluded that the steel section and the composite section Type 2 have the maximum seismic base reactions. The relevant models, compared with the Models 8-2 and 8-4 are of more stiffness. They have weak performances against the lateral loads of earthquake and therefore they are disabled to dissipate the seismic energy effectively. Models 8-2 and 8-4 with composite column sections Type 1 and 3 respectively, have the least values of seismic base reactions. Ductility and good performance against lateral dynamic loads and the ability of dissipating input seismic energy are the properties of these two systems compared with the other types. Composite sections Type 1 and 3 (full and half embedded IPB sections in concrete) have lesser values of base reactions about $18 \%$ and $21 \%$, respectively, compared with the Model 8-1 (IPB column sections) which has the greatest values of base reactions.

\section{References}

[1] Begum, M., Driver R.G., Elwi A.E., Behaviour of partially encased composite columns with high strength concrete, Journal of Engineering Structures, (2013) pp. 1718-1727.

[2] Hajjar F., Composite steel and concrete structural systems for seismic engineering , Journal of Constructional Steel Research, (2002) pp. 703723 http://dx.doi.org/10.1016/S0143-974X(01)00093-1.

[3] Ellobody E., Young B., Lam D., Eccentrically loaded concrete encased steel composite columns, Thin-Walled Structures , Journal of Constructional Steel Research (2011), pp. 211-222.

[4] Saw H.S., Richard Liew J.Y., Assessment of current methods for the design of composite columns in buildings , Journal of Constructional Steel Research, (2000) pp. 121-147 http://dx.doi.org/10.1016/S0143-974X(99)00062-0.

[5] Estekanchi H.E., Valamanesh V., Vafai A., Application of endurance time method in linear seismic analysis, Journal of Engineering Structures, (20007) pp. 2551-2562.

[6] Gramblicka S., Lekles A., Analysis of Composite Steel-concrete Columns, Journal of Procedia Engineering,(2012) pp. $247-252$. 